\title{
Management through the Lenses of Ancient People
}

\author{
Ezgi Yildirim Saatci
}

\begin{abstract}
Management" as a science, emerged late in the $19^{\text {th }}$ century, gained respect and peaked in academic world to the end of $\mathbf{2 0}^{\text {th }}$ century. Now, it is a fundamental school of concept for all kind of works no matter of its orientation either as business or engineering. In this paper, it is aimed to emphasize popular managerial concepts and buzzwords with ancient people sayings from Egypt, Babylonia, China, and Greece. Accordingly, organization and departmentalization, and human resources management in Ancient Egypt, Hammurabi's codes and its reflections to bureaucracy in Ancient Babylonia, organizational strategy and ethics in Ancient China, and division of labor, human resources management and leadership in Ancient Greece are explored.
\end{abstract}

Index Terms-Management, ancient world, organizational strategy.

\section{INTRODUCTION}

The ancient world was and remained to be the one of the most amazing subject for researchers, academics and students. The base of the most sciences such as medicine and law has roots to ancient Egypt, Babylonia, China, and Greece. The "management" concept has no difference from other sciences and showed itself as early as thousands years B.C. in the form of administration.

Administrative operations of ancient people, reflecting very old part of the intelligence of mankind found their terminologies in $1900 \mathrm{~s}$ with decorated and modernly jargonized management terms. Therefore, this paper aims to take a journey in exploring the most significant applications of the management concept in the ancient world with respective chronological order of ancient Egypt, Babylonia, China, and Greece.

The chapter followed by the introduction is Ancient Egypt. In this part organization and departmentalization, human resources management and reporting examples from Ancient Egypt are discussed in detail.

Ancient Babylonia is the second civilization discussed. Economic success and laws built up to the success of Babylonia. The Hammurabi codes established the success of Babylonia and besides Hammurabi's codes is perceived as the basis of some dimensions of legislation system, it also takes credits as it mainly a system based on bureaucracy. Hammurabi's codes and its reflections to bureaucracy are discussed for this part of the report.

Ancient China is evaluated as the coming subject. In the

Manuscript received July 27, 2013; revised October 16, 2013.

Ezgi Yıldırım Saatci is with the Faculty of Economic and Administrative Sciences of Okan University and managing director of Okan University Social Entrepreneurship and Social Responsibility Research Center (e-mail: ezgi.saatci@okan.edu.tr). ancient China, two important characters played an important role for nowadays management concept. One of them was Chinese general Sun-Tzu and the other one was the famous philosopher Confucius. Sun Tzu is investigated for the strategy and Confucius is investigated for the business ethics in managerial norms.

Ancient Greece is explored in Organizational Strategy, division of labor, human resources management and leadership dimensions. Especially the famous philosophers Aristotle, Plato and Socrates had visionary insights about these managerial concepts.

\section{ANCIENT EGYPT}

About 5,000 years ago in Mesopotamia, and shortly thereafter in Egypt, the emergence of ruling classes, religion, writing, and cities formed the bases of the civilization with its seeds to the many sciences such as management. For instance, thousands of years before Christ, ancient Egypt saw the introduction of 'The Book of the Dead' which may be considered as the first documented quality system on earth which contained detailed procedures that needed to be followed to prepare the body and soul for the afterlife [1].

\section{A. Organization and Departmentalization}

The organizational concepts in ancient Egypt surfaced in the project forms of "temple building". The palace had a number of departments to help administer the redistributive economy. The central authority and significant measure of centricity (goods' flowing into the centre and out of it again) could be considered as a facilitator of state bureaucracy related operations [2].

Bureaucratic control was established on a system of "crews" through dividing the population into several distinct groups.. The crew had an internal structure and was made up of two gangs, a gang was divided into four or five phyles, and each phyle had four divisions of about 10 men each [3]. This practice constituted "rule of ten" that emerges 10 people for 1 supervisor within the span of control which was later used in various civilizations as well as modern army structures.

In contemporary terms, as Wren notes the methodology used in ancient Egypt was "managing through forecasting, planning work, dividing the work among the people and departments and establishing a Professional full time administrator to coordinate and control the state enterprise" [4].

From the control measures sides, ancient Egyptians wisely used multi criteria such as: (i) output control forms, showing for each workman his location, number of stones requested, number delivered, and the remaining balance for every working day; (ii) control notes which provided information about dates, procedures for transporting stones and the 
workmen involved; (iii) team marks (which identified the specific division, phyle and gang); and (iv) setting marks intended to ensure that the stones were assembled in the right order[5].

\section{B. Human Resource Management}

Ancient Egyptians experienced newly popularized human resources management terms in practice back in BC eras through setting up each division with a specific name, attributing to a specific phyle and classifying under a particular gang with respect to trace responsibility of individual workmen, to check their absence or presence, and to rotate them either individually or in groups [5]. The comprehensive work of these records is presented in Table I:

TABLE I: ATTENDANCE LIST: PAPYRUS REISNER I [6]

\begin{tabular}{|c|c|c|c|}
\hline List of Workmen & TotalDays & $\begin{array}{c}\text { Days } \\
\text { onProject }\end{array}$ & $\begin{array}{c}\text { Days } \\
\text { ofAbsence }\end{array}$ \\
\hline Oker's son & & & \\
\hline Sobk-hotpe & 11 & 11 & \\
\hline His brother Inyotef & 11 & 8 & 3 \\
\hline $\begin{array}{l}\text { Ketiu's son Nedjes } \\
\text { Se'n-Worset's son }\end{array}$ & 75 & 42 & 33 \\
\hline $\begin{array}{l}\text { Sehetep-ib } \\
\text { Inyotef's son }\end{array}$ & 75 & 46 & 29 \\
\hline $\begin{array}{l}\text { Nesu-Mentu } \\
\text { Ameny's son }\end{array}$ & 75 & 65 & 10 \\
\hline Nefer-Kha u & 75 & 75 & \\
\hline $\begin{array}{l}\text { his brother Sefkhy } \\
\text { Sobk-hotpe's son }\end{array}$ & 75 & 75 & \\
\hline $\begin{array}{l}\text { Nakhti's son Inyotef } \\
\text { Sobek-nakhte's son }\end{array}$ & 11 & 9 & 2 \\
\hline $\begin{array}{l}\text { Mereri } \\
\text { Hedejenenu's son }\end{array}$ & 75 & 60 & 15 \\
\hline $\begin{array}{l}\text { Mer-su } \\
\text { Sobk-hotpe's son }\end{array}$ & 11 & 11 & \\
\hline $\begin{array}{l}\text { Anhur-ankhu } \\
\text { H Nefer-tjentet's son }\end{array}$ & 11 & 11 & \\
\hline Se n-Wosret & 75 & 55 & 20 \\
\hline Total & 580 & 468 & 112 \\
\hline
\end{tabular}

TABLE II: DISTRIBUTION OF RATIONS: INSCRIPTIONS OF SINAI [5]

\begin{tabular}{|c|c|c|c|c|}
\hline Occupation & $\begin{array}{l}\text { Daily } \\
\text { Bread }\end{array}$ & $\begin{array}{l}\text { Loaves } \\
\text { Multiplier }\end{array}$ & $\begin{array}{l}\text { Daily } \\
\text { Beer }\end{array}$ & $\begin{array}{l}\text { Units } \\
\text { Multiplier }\end{array}$ \\
\hline & 10 & & & \\
\hline 1. Unskilled workers & loaves & 1 & $1 / 3$ unit & 1 \\
\hline 2. Seal bearers, & 15 & & $47 / 60$ & \\
\hline guardsmen and hunters & $\begin{array}{c}\text { loaves } \\
20\end{array}$ & 1.5 & unit & 2.35 \\
\hline 3. Craftsmen & loaves & 2 & $1 / 2$ unit & 1.5 \\
\hline $\begin{array}{l}\text { 4. Royal retainers, } \\
\text { scribes and the }\end{array}$ & 30 & & & \\
\hline $\begin{array}{l}\text { chamberlain } \\
\text { 5. Stewards of the Great }\end{array}$ & $\begin{array}{l}\text { loaves } \\
50\end{array}$ & 3 & 1 unit & 3 \\
\hline $\begin{array}{l}\text { Board and Treasury } \\
6 . \text { The Greatest of the } \\
\text { Thirty of Upper }\end{array}$ & loaves & 5 & 2 units & 6 \\
\hline $\begin{array}{l}\text { Egypt, mayors, and the } \\
\text { commander Sankh-ptah }\end{array}$ & $\begin{array}{c}100 \\
\text { loaves } \\
200\end{array}$ & 10 & 3 units & 9 \\
\hline 7. The herald Ameni & loaves & 20 & 5 units & 15 \\
\hline
\end{tabular}

Furthermore, based on the workers' presence, compensation system was developed with differential payments to the personnel. The Inscriptions of Sinai shows the wage documents (Table II) where, the scribe used 'basic wage' multiples to differentiate payments to personnel occupying different positions.

\section{ANCIENT BABYLONIA}

Babylonia was an ancient Acadian state based in south Mesopotamia in 18th century BC. Babylon is known to be the first empire where anyone could and would conduct the business and where the responsibility of the king was merely being commercially active. It was a place where commerce became part of the religion allowing all religious places to perform commercial activities. The property stake and personal seals, keeping track of who owned what, originated in Babylon formed the notion of private property which in turn provided the power notion that was obtained through economic success [7].

\section{The Administration and Bureaucracy}

Hammurabi, king of Babylonian, ruled the Babylonian Empire for 42 years from 1792-1750 BC, during which, political, cultural, and religious activities were peaked in Mesopotamia. He was a military man who dominated many of his neighboring cities but he is mostly recognized for his contributions to the fields of administration and law [8], [9].

At the end of his long period of influence, Hammurabi's legal decisions were collected and emblazoned on a stone tablet that showed 282 laws known as "the Code of Hammurabi". Apart being significant for legal concepts, these codes also indicated major administrative rules. For instance; code number 72 says that:

"If a builder builds a house for a man and does not make its construction firm, and the house which he has built collapses and causes the death of the owner of the house, that builder shall be put to death."

It was Hammurabi who first established the principle that a manager was responsible for his workers; each act of a laborer or apprentice was considered the act of the contractor itself can be seen in Frederick Taylor's most enduring management principle of the 20th century emphasizing "management does the thinking (takes responsibility for the work) while labor carries out the plan (follows orders)" [10].

With all the aspects of Hammurabi's administration, it can be said that public administration in the First Babylonian Dynasty under the rule of Hammurabi had many of the characteristics of Weber's ideal type bureaucracy. There were at least three classes (as opposed to levels) of subordinates: rabianum who were the highest; satammu or minor officials; and the lowest class constituted of laborers and herdsmen. Hierarchy and class structures were very important in the form of governance. In other words, the Hammurabi administration achieved 3800 years ago what Weber describes as a modern bureaucratic phenomenon [11].

\section{ANCIENT CHINA}

Similar to all ancient civilizations, architectural designs, temple buildings, philosophical conversations held in different eras of China between dynasties of Shang and Zhou specifically indicates early managerial applications. High levels of centralization, cost control, inspection, and 
employee training characterize the history of administrative procedures in ancient China over Frederick Taylor's scientific management.

In the ancient China, two important characters played an important role for nowadays management concept. One of them was Chinese general Sun-Tzu and the other one is the famous philosopher Confucius. Accordingly, the ties of ancient China to the management concept can be explored with these people regarding the strategy and organizational behavior and ethics respectively.

\section{A. Strategy}

"Art of War" - the book that covers the philosophical essence of a Chinese warrior and philosopher named Sun Tzu- is considered as a bible of strategy. Being formed 2500 years ago, still those seeking to understand strategy in all aspects of business and life have also turned to Sun Tzu on the Art of War for the intelligence and insights therein [12]

Nowadays "win-win" strategies are in the ground rules of Sun-Tzu strategy emphasizing two principal lessons: war and its avoidance for the sake of loss minimization as he mentioned that even military victory is defeat in the sense that it requires an expenditure of the state's manpower and resources. For this reason, war is acceptable only when all possible alternatives have been exercised with the utmost goal of victory at the minimum cost [13]. Within all strategies there lie six Sun Tzu principles:

1) Winning Whole - How to succeed with your resources and your objective intact which can be referred to the planning part of the management concept

2) Leading to Advantage - How to prepare and position your soldiers for victory which can be found in modern era human resource management

3) Deception - How to keep your intentions secret from opponents which points out the privacy and legacy of information

4) Energy - How to apply force effectively and efficiently that is still the main focus of organizations.

5) Strengths and Weaknesses - How to find the best path to the goal directly relating the importance of strategy to decision making as the SWOT analysis of the organizations addresses

6) Initiative - How to take and keep the advantage in a conflict as in the case of competitive advantage in terms of recognition, survival, profit orientation of today's businesses.

\section{B. Organizational Behavior and Ethics}

Wren (2005) mentions that "Confucius (552-479 B.C.) left his mark on the ages through his moral teachings and through his advocacy of a merit system" [14].

At the individual level, the golden rule defined by Confucius as "What I do not wish men to do to me, I also wish not to do to men." [15] forms the basis of all principles and virtues stated by Confucius.

According to the Confucius, "a moral person needs to evaluate behavior by its impact on both the individual and others. The virtue is relational and the parties must demonstrate trust as a quality. Trust, therefore, must be earned" [16].
Leadership aspect of Confucius remained on the same ground of morality. Several quotations given below can be considered as the illustration of moral leadership of those in power:

"The superior man has nine things which are subjects with him of thoughtful consideration. In regard to the use of his eyes, he is anxious to see clearly. In regard to the use of his ears, he is anxious that he hears distinctly. In regard to his countenance, he is anxious that it should be benign. In regard to his demeanor (sic), he is anxious it should be respectful. In regard to his speech, he is anxious that it should be sincere. In regard to his doing business, he is anxious that it should be reverently careful. In regard to what he doubts about, he is anxious to question others. When he is angry, he thinks of the difficulties. When he sees gain, he thinks of righteousness". [17]

The "sine qua non" of being a human is being a part of a society. Relationships and dependencies are organized according to the morality which is a sum of complex interrelationships and interdependencies of people in this society.

Therefore at the macro level, Confucianism consent the organization more than a single purpose entity. Nowadays "Corporate Social Responsibility" and "Socially Responsible Business" gain interest based on the grounds set by Confucian envisaging an organization to be a community with multiple goals including profit, survival, service, and ethics.

Organizational behavior related principles can be seen in his mentioning about the Rites. According to Confucius; participation in the Rites is on three levels. On the first level for the rite to have meaning it must be appropriate to the circumstance. Therefore at this level, modern eras' goal orientation and macro planning can be sensed in a way that to succeed, patterns, sequence of events and processes needed to achieve goals must be determined. At the second level, many roles must be performed properly, and the participants must have the appropriate preparation indicates job description and person-job fit with clear indication of "people must be selected for the knowledge and skills necessary to fulfill their roles". Finally at the third level, Rites require cooperative behavior, the fulfilling of roles appropriate to each participant's capabilities as well as the flow of the ceremony, ceremonial knowledge, and the desire that form today's teamwork and motivation as well as organizational learning through cooperation and subordination of themselves, their activities and their collective efforts for the accomplishment of the common purpose.

\section{ANCIENT GREECE}

Greece was populated in the Paleolithic period and by $3000 \mathrm{BC}$ and onward had become address of history, culture, religion and language as well as literature as seen by the temples, sculpture, pottery, objects and other archaeological findings [18].

Those findings, as well as the writings of Herodotus, father of history-, Thucydides and Xenophon helped shaping 
the some managerial models and techniques that are used in organizations for the time being such as organizational strategy, leadership and ethics.

\section{A. Strategy}

Organizational strategy is considered to be a primary topic and the history of strategy and strategic management covers a broad timeline from ancient Greece to the twenty-first century [19].

Concerning the strategy Socrates covered the concept as follows:

"Those who do not know and dare self deluded as their capabilities...neither what they want, nor what they are doing, nor with whom they are dealing. Mistaken in all these respects, they fall short of the good and fall into the bad. Those who know what they are doing, get the object of their business and win a good reputation and honors. Their peers are delighted to deal with them, and those who are unsuccessful in their business want them to offer advice on their affairs, take them as their leaders, and rest on them their hopes of good things to come, and for all these reasons are fond of them above all other men." [20]

Another Greek philosopher who contributed to development of strategy is Aristotle (384-322 BCE) According to Aristotle, practical wisdom involves the virtuous capacity to make decisions and take actions that promote the 'good life' for the 'polis' which implies an organizational practice that involves taking action even when decision factors are clouded by ambiguity and uncertainty seeking consciously and intentionally to produce the good for the entire organization as well as the community that sustains it [21].

\section{B. Management and Division of Labor}

Apart from the strategy, there was a clear distinction of business concept from the administration enriched with leadership visions and management views. Observations of some of the Greek philosophers' such as Socrates, Plato and Aristotle, reflects concrete examples about management in Ancient Greece. Plato (428-348 BC) outlined human diversity and division of labor [18] with the following words as states by Aristotle:

"A State . . arises . . out of the needs of mankind; no one is self-sufficing, but all of us have many wants. ... As we have many wants, and many persons are needed to supply them, one takes a helper for one purpose and another for another; and when these partners and helpers are gathered together in one habitation the body of inhabitants is termed a State. . . And they exchange with one another, and one gives, and another receives, under the idea that the exchange will be for their good" [22]

Socrates observed the managerial skills and differentiated from the administration as follows:

"It is not the task of both the good business man and the good general to make their subordinates compliant and obedient? And to entrust individual matters to the individuals suitable to them? I also think that it is incumbent on both to punish the bad and honor the good... When it comes to the question of "what help business knowledge will be, once it comes to fight" this is where it will be most helpful. For the good business man, realizing that nothing is as advantageous and profitable as defeating one's enemy in battle, and nothing is so disadvantageous and financially ruinous as defeat, eagerly will search out and prepare what is conducive to victory, and will attentively consider and guard against what leads to defeat. Should he see that he has the resources to win, he will actively fight. But above all, if he finds himself unprepared, he will be careful not to join the battle" [23]

"Don't look down on business man. For the management of private concerns differs from that of public concerns only in magnitude...neither can be carried without man... and those who understand how to employ(others) are successful directors of private and public concerns, and those who do not understand, will err in the management of both" [24].

\section{CONCLUSION}

This paper covers a miniature yet significant portion of powerful ancient civilizations' applications through the words of ancient people in relation to managerial concepts of nowadays. Civilizations such as Ancient Egypt, Babylonia, Ancient China, and Ancient Greece based on the grounds of administrative applications with managerial implications of strategy, organizational behavior, leadership and ethics are evaluated. Managerial thought and seeds of organizational theory with division of labor and bureaucracy can be argued to be developed back then.

As discussed throughout the paper, new trends propagated by management gurus can be considered as a wisdom transfer of mankind through generations and stem from ancient ancestors. Therefore the concept of management can be further analyzed with other areas of management such as finance and accounting and further researches can cover the heritage of ancient civilization as long as it concerns human beings.

\section{REFERENCES}

[1] S. Quirke, The Administration of Egypt in late Middle Kingdom, New Madlen Surrey: SIA Publishing, 1990.

[2] B. J. Kemp, Ancient Egypt: Anatomy of a Civilization, London: Routledge, 1989.

[3] A. M. Roth, Egyptian Phyles in the old Kingdom, Chicago, IL: Oriental Institute of the University of Chicago, 1991.

[4] D. A. Wren, The History of Management Thought, Fifth Edition Published By John Wiley \& Sons, Inc. UK, pp. 42, 2005.

[5] M. Ezzemel, "Work organization in the middle kingdom, ancient Egypt," Organization, vol. 11, no. 4, pp. 497-537, 2004.

[6] W. K. Simpson, Papyrus Reisner I: The Records of a Building Project in the Reign of Sesostris, I. Boston, MA: Museum of Fine Arts, 1963.

[7] J. Nirenberg, Overcoming Hammurabi's Curse -- The Realpolitik of Building New Organizations, ebook Amazon, 2002.

[8] J. Reade, Mesopotamia, Cambridge, MS: Harvard University Press, 1991.

[9] A. M. Roth, Egyptian Phyles in the Old Kingdom, Chicago, IL: Oriental Institute of the University of Chicago, 1991.

[10] J. Nirenberg, Overcoming Hammurabi's Curse-The Realpolitik of Building New Organizations, ebook Amazon, 2002.

[11] M. G. Alkadry, "Weber's or Hammurabı's? Ideal or Anc1ent?” Public Administration Quarterly, vol. 26, issue 3-4.

[12] R. L. Cantrell, Understanding Sun Tzu on the Art of War, Published by: Center for Advantage Arlington, 2003. 
[13] S. P. Arthy, The Art of Combat Ancient Wisdom for the Competitive Economy, Published by John Wiley \& Sons, Inc. UK, 2001.

[14] D. A. Wren, The History of Management Thought, Fifth Edition Published by John Wiley \& Sons, Inc. UK, pp. 56, 2005.

[15] H. Fingarette, Confucius: The Secular as Sacred, Waveland Press, Prospect Heights, IL, pp. 34, 1998.

[16] H. Fingarette, Confucius: The Secular as Sacred, Waveland Press, Prospect Heights, IL, pp. 46, 1998.

[17] D. A. Wren, The History of Management Thought, Fifth Edition Published By John Wiley \& Sons, Inc. UK, pp. 67, 2005.

[18] D. A. Wren, The History of Management Thought, Fifth Edition Published By John Wiley \& Sons, Inc. UK, 2005.

[19] P. S. Chinowsky and J. E. Meredith, "Strategic Management in Construction," Journal or Construction Engineering and Management, vol. 126, no. 2, pp. 1-9, 2000.

[20] Brennan et al., "Xenephon, Socratic Memoirs," Wisdom from the Ancients, Published by: Perseus Publishing, Cambridge, pp. 27, 2001.

[21] P. Baumard, Tacit Knowledge in Organisations, London: Sage, 1999.

[22] M. E. Williamson, "Specialization and the division of labor in the social thought of Plato and Rousseau," The Journal of Libertarian Studies, vol. 4, no. 1, pp. 87, 1980.

[23] Brennan et al., "Xenephon," Socratic Memoirs, Wisdom from the Ancients Published by: Perseus Publishing, Cambridge, pp. 65, 2001.

[24] D. A. Wren, The History of Management Thought, Fifth Edition Published By John Wiley \& Sons, Inc. UK, pp. 43, 2005.

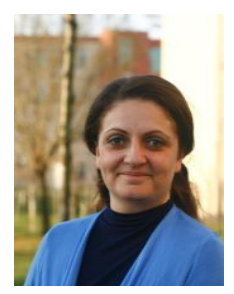

Ezgi Yildirim Saatci was born in Ankara Turkey at 17th of March 1974. Her academic career includes B.Sc. in Management from Middle East Technical University, Ankara-Turkey (1997) with high honor degree, M.Sc. in Management and IS from London School of Economics, London UK (1998) with the thesis of "Change Management and Groupware Applications", completed with distinction. She has received her Ph.D. degree in Management and Organization with the dissertation titled "Effect of Board Governance Roles on Company Performance" from Yeditepe University, Istanbul Turkey (2011).

She worked as business management consultant in deloitte and touche, business development manager in netbul.com, marketing manager in filpark, and general manager at techco corp. she is currently ass. professor of management at okan university, turkey and deputy managing director of "muhammad Yunus International Center for Microfinance and Social Business", a center founded in 2011 to enhance the education, research and practical applications of social entrepreneurship within the area. She is teaching Strategy, Entrepreneurship, Social Business, Human Resources Management and E-business. She is also the editor of Prof. Yunus Lecture Proceedings, University Publications. She has articles on Women Entrepreneurship, Youth Entrepreneurship and Social Business Cases working papers.

Prof. Saatci is currently active in Turkish Entrepreneurship Workshop, Projects run for Local Governmental Agencies and Regional NGOs and Comparative Studies on Social Business Applications. She is married with two sons and resides in Istanbul, Turkey. 